dr inz.Zygmunt Marciniak, prof. nadzw.

mgr inz. Piotr Michalak

Instytut Pojazdów Szynowych ,TABOR”

\title{
Nowe rozwiązania i układy w zmodernizowanej lokomotywie spalinowej typu 303Da serii ST46 do ruchu towarowego
}

\begin{abstract}
Artykut jest poświęcony prezentacji nowych i modernizowanych ukladów, systemów, zespotów $i$ urzadzeń zastosowanych $w$ modernizowanej lokomotywie spalinowej serii SU46 (po modernizacji ST46) przeznaczonej zasadniczo do prowadzenia pociagów towarowych. W artykule zaprezentowano charakterystyki trakcyjne i możliwości przewozowe lokomotywy oraz uzyskane parametry techniczne i eksploatacyjne lokomotywy oraz jej głównych zespołów i ukladów. Ponadto opisano nowe $i$ zmodernizowane zespoty $i$ uktady oraz przedstawiono zakres zrealizowanych prób $i$ badań stacjonarnych, ruchowych i eksploatacyjnych pozwalajacych na dopuszczenie jej do ruchu na torach PKP PLK S.A. Referat powstat w ramach zrealizowanego w 2011r. projektu celowego $\mathrm{nr}$ 6ZR 2009 C/07187 p.n. ,Zmodernizowana lokomotywa spalinowa serii SU46 przystosowana do wymagań TSI obowiazujacych w Unii Europejskiej” wykonanego przez Instytut Pojazdów Szynowych „,TABOR” w Poznaniu i Pojazdy Szynowe „PESA” Bydgoszcz S.A.
\end{abstract}

\section{Wprowadzenie}

Lokomotywa spalinowa serii SU46 (303D) została zaprojektowana w Ośrodku BadawczoRozwojowym Pojazdów Szynowych w Poznaniu (obecnie IPS TABOR Poznań) w 1972r. jako kontynuacja serii lokomotyw SP45 (301Db) przerobionych na SU45.
Lokomotywy były produkowane w latach 19741977 przez Fabrykę Wagonów i Lokomotyw W3 Zakładów Przemysłu Metalowego H. Cegielski w Poznaniu. Ogółem wykonano 52 lokomotywy i były one pierwszymi krajowymi lokomotywami spalinowymi przystosowanymi do elektrycznego ogrzewania 
wagonów w systemie $3 \mathrm{kV}$ zapewnionego przez prądnicę prądu przemiennego.

W 1985r. po niewielkich modyfikacjach wyprodukowano 2 szt. tych udanych polskich lokomotyw.

Obecnie lokomotywy serii SU46 wykorzystywane są w ruchu pasażerskim i towarowym. Lokomotywy spalinowe SU46 (303D) od ponad 30 lat nie podlegały żadnym znaczącym modernizacjom. Dopiero w 2009 r. po ogłoszeniu przetargu przez PKP CARGO S.A. oraz postawieniu nowych wymagań w Instytucie Pojazdów Szynowych „TABOR” w Poznaniu i w Pojazdach Szynowych PESA Bydgoszcz S.A. rozpoczęto pracę nad modernizacją lokomotywy spalinowej serii SU46 spełniająca wymagania stawiane przez przyszłego Użytkownika oraz przystosowaną do wymagań technicznych specyfikacji interoperacyjności obowiązujących w Unii Europejskiej. Ponadto po modernizacji lokomotywy przeznaczone zostaną tylko do prowadzenia pociagów towarowych (oznaczenie kolejowe ST46-303Da) zarówno na torach PKP PLK S.A. jak i torach DB w ruchu transgranicznym.

Głównymi celami modernizacji stawianymi przez Użytkownika będzie zmniejszenie zużycia paliwa, ograniczenie szkodliwego oddziaływania na środowisko naturalne w tym zmniejszenie udziału emisji do atmosfery składników toksycznych spalin takich jak $\mathrm{CO}, \mathrm{HC}, \mathrm{NOx}$, cząstki stałe (spełnienie poziomu IIIa, a od 2012r. również poziomu IIIb), zmniejszenie wydzielania $\mathrm{CO} 2$, zwiększenie przebiegów eksploatacyjnych pomiędzy wykonywanymi przeglądami i naprawami oraz zwiększenie trwałości i niezawodności lokomotywy dzięki zastosowaniu nowoczesnych i trwałych aparatów, urządzeń i elementów o wydłużonym czasie eksploatacji.

Ponadto zmodernizowana lokomotywa bedzie cechować się ograniczoną emisją hałasu wewnętrznego i zewnętrznego, mniejszymi wartościami pola magnetycznego w kabinach oraz nowymi rozwiązaniami w kabinach poprawiających bezpieczeństwo oraz komfort pracy i obsługi.

Wymagania stawiane modernizowanym pojazdom trakcji spalinowej (w tym lokomotyw spalinowych) były i są realizowane $\mathrm{z}$ powodzeniem zarówno przez IPS „TABOR” w Poznaniu jak i innych wykonawców (producentów). Szczegółowe opisy i uzyskane parametry przedstawiono między innymi w $[1,2]$.

Mamy nadzieję, że po dobrze zrealizowanej modernizacji pierwszej polskiej lokomotywy liniowej SU45 (przekształconej w serię ST45) wykonanej na 11 egzemplarzach, modernizacja lokomotyw serii SU46 obejmie również znaczącą ich liczbę. Obecnie w posiadaniu i eksploatacji PKP CARGO S.A. znajduje się około 30 sztuk lokomotyw serii SU46 (303D) [3].

\section{Charakterystyka trakcyjna i parametry zmo- dernizowanej lokomotywy transportu}

Zmodernizowana lokomotywa serii SU46 (po rezygnacji z prądnic grzewczych) przeznaczona będzie do prowadzenia [3]:

- pociagów pasażerskich (w okresach letnich) o masie do 430 ton na pochyleniu $0 \%$ z prędkością $100 \mathrm{~km} / \mathrm{h}$

- pociagów towarowych o masach do 1700 ton na pochyleniu $0 \%$ z prędkościami do $80 \mathrm{~km} / \mathrm{h}$

- pociagów towarowych o masach do 1500 ton na pochyleniu 3\% z prędkościami do $60 \mathrm{~km} / \mathrm{h}$

Ponadto możliwości trakcyjne lokomotywy umożliwiać powinny (przy zachowaniu oporów ruchu dla lokomotywy przed modernizacją) ruszenie $\mathrm{z}$ pociągiem o masie brutto 1500 ton na pochyleniu $10 \%$.

Charakterystykę trakcyjną modernizowanej lokomotywy przedstawiono na rys.1, a jej możliwości trakcyjne na rys. 2 . 


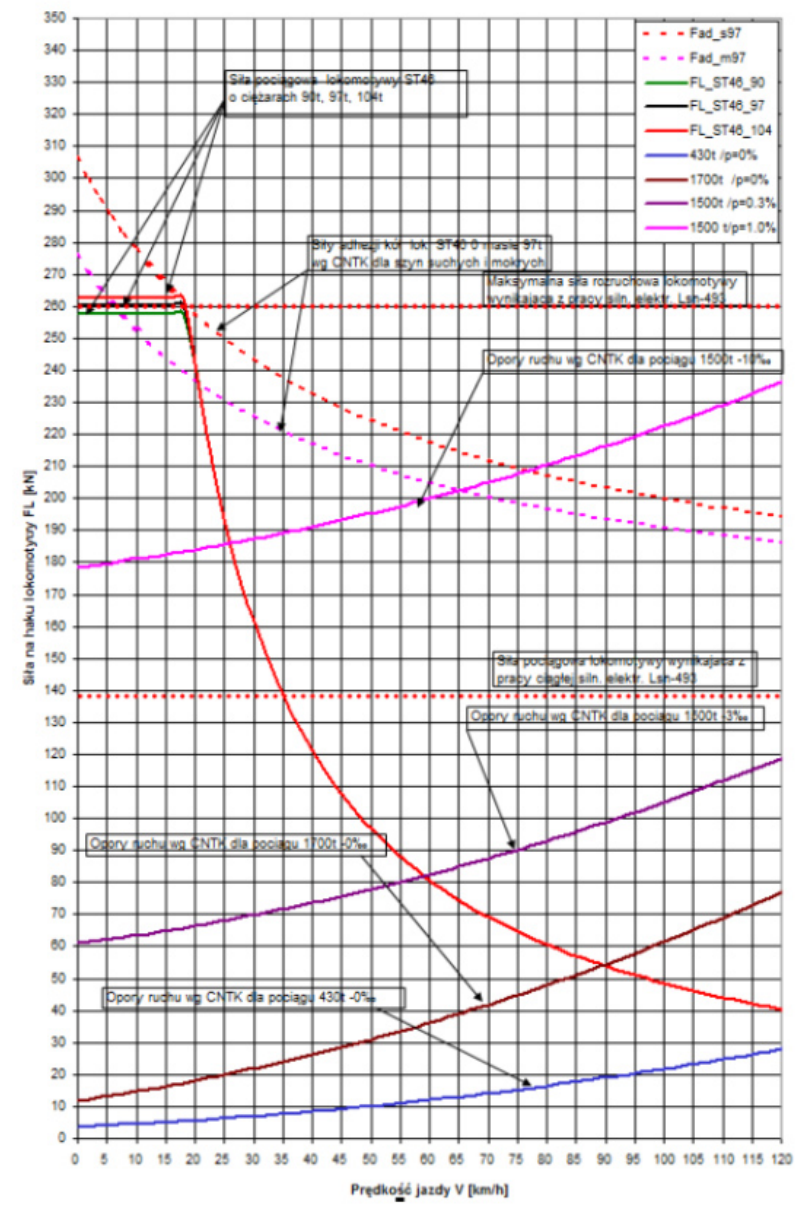

Rys.1 Charakterystyka trakcyjna

\section{Nowe i zmodernizowane zespoły i uklady loko- motywy}

Zakres modernizacji dotyczył większości zespołów i układów lokomotywy co umożliwiało uzyskanie nowoczesnej lokomotywy charakteryzującej się następującymi rozwiązaniami:

- nowoczesnym silnikiem spalinowym o mocy $1800 \mathrm{~kW}$ spełniającym podstawowe wymagania w zakresie emisji spalin (zgodnie z poziomem IIIa), dużą niezawodnością (24000 godzin do naprawy głównej), małym zużyciem paliwa przy mocy znamionowej $(210 \mathrm{~g} / \mathrm{kWh})$ i małym zużyciem oleju $(<1,05 \mathrm{~g} / \mathrm{kWh})$

- nowoczesnym zespołem prądnic synchronicznych bezszczotkowych o mocach - główna $1500 \mathrm{~kW}$ i pomocnicza $-100 \mathrm{~kW}$ przekształcanych w czterech statycznych przetwornicach do zasilania odbiorników układów pomocniczych. Do dyspozycji są dostępne napięcia $3 x 400 \mathrm{VAC}, 230 \mathrm{VAC} 50 \mathrm{~Hz}$ i $28 \mathrm{VDC}$

- napędami pomocniczymi (sprężarki, wentylatorów silników trakcyjnych, wentylatorów zespotu chłodnic) wykorzystującymi silniki prądu przemiennego i silniki hydrauliczne

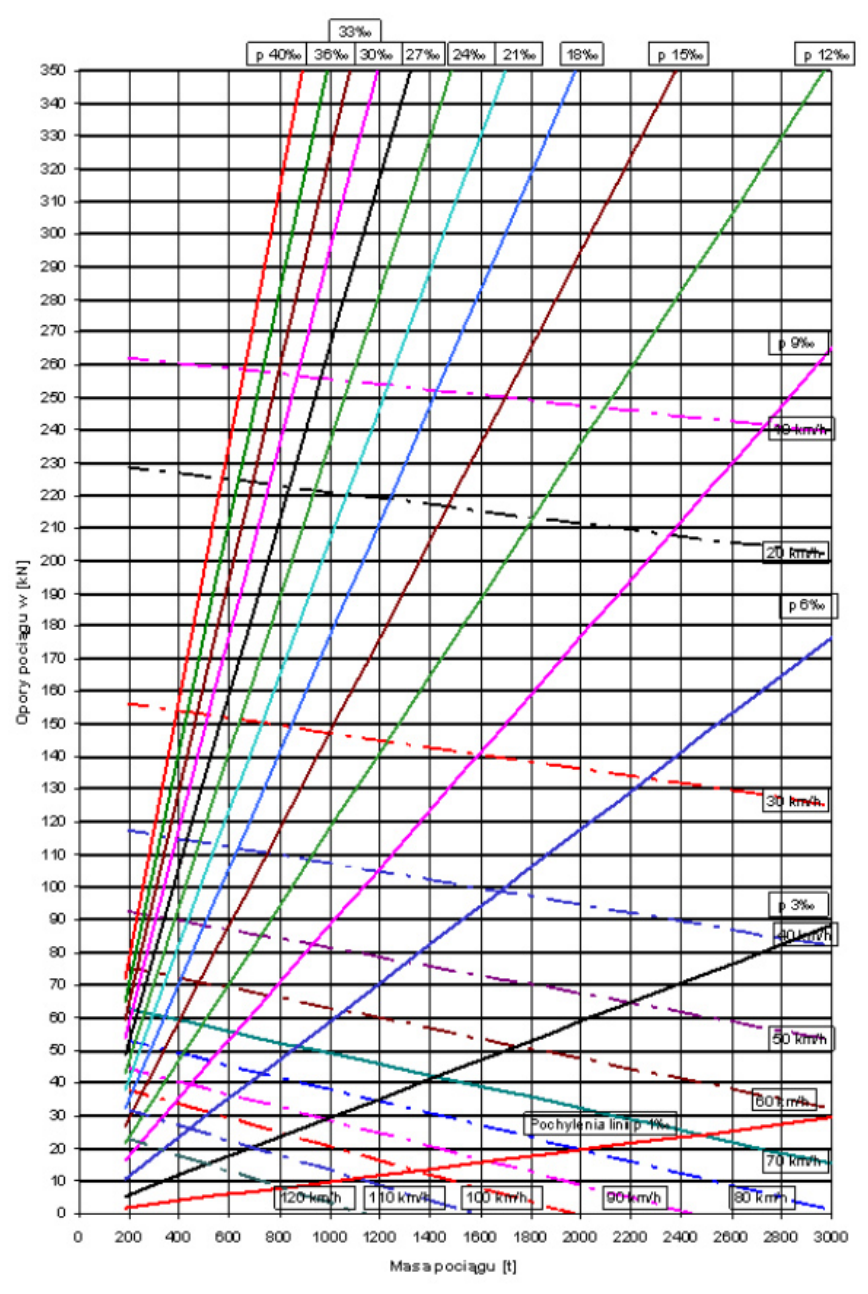

Rys. 2 Możliwości trakcyjne

- zrekonstruowanym układem pneumatycznym i hamulca skupiającym aparaty pneumatyczne na tablicy, hamulcem postojowym wyposażonym w siłowniki sprężynowe oraz układem przeciwpoślizgowym i sprężarką śrubową

- zmodernizowanymi wózkami trakcyjnymi z wprowadzonymi dodatkowymi podparciami i zmienionym prowadzeniem środkowych zestawów kołowych, wyposażonymi w olejowy układ smarowania obrzeży kół i zlikwidowanym sprzęgiem miedzywózkowym

- mikroprocesorowym elektronicznym układem sterowania i diagnostyki lokomotywy współpracującym $\mathrm{z}$ autonomicznymi sterownikami głównych zespołów i komunikacji zgodnymi ze standardami CAN(bus)

- urządzeniami i aparatami bezpieczeństwa i radiołączności (dualnymi) zgodnymi z wymaganiami kolei polskich i niemieckich oraz spełniającymi wymagania $\mathrm{w}$ zakresie interoperacyjności dla kolei konwencjonalnych

- układem wykrywania i sygnalizacji pożaru oraz stałą instalacją gaszącą na mgłę wodną 
- zmodernizowanymi kabinami sterowniczymi zapewniającymi pełne bezpieczeństwo i komfort dla maszynistów i pomocników dzięki zastosowaniu nowoczesnych układów pulpit (główny i pomocniczy)- fotel, kamer umożliwiających obserwację do tyłu, schładzaczy dachowych z możliwością dogrzewania, nową izolacją akustyczną i termiczną gwarantującą tłumienie dźwięku i komfort cieplny, wyłożeniami z płyt poliwęglanowych i laminatów poliestrowo-szklanych, oświetleniem wnętrza z możliwością regulacji natężenia, szybami elektrogrzejnymi oraz wyposażonymi w szafki odzieżowe, umywalkę, płytę grzewczą i szafkę narzędziową.

Pozostałe nowe urządzenia $\mathrm{i}$ aparaty zastosowane $\mathrm{w}$ zmodernizowanej lokomotywie zostały szczegółowo zaprezentowane w [3].

Widoki lokomotywy, zmodernizowanych oraz nowych zespołów i układów przedstawiono na rys. $\div \div 9$ a rozmieszczenie głównych maszyn i zespołów w zmodernizowanej lokomotywie przedstawiono na rys. 10.

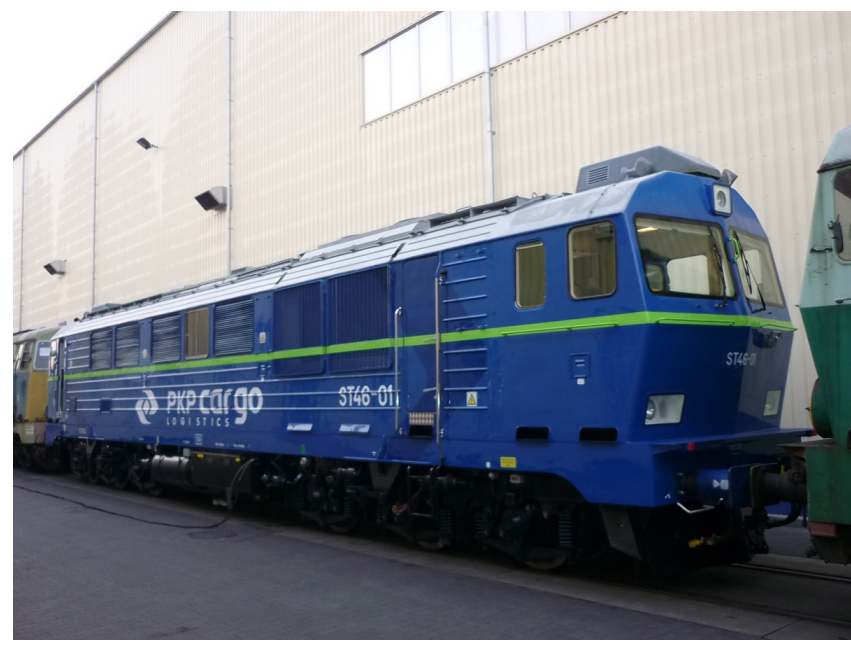

Rys.3 Widok zmodernizowanej lok. serii ST46 (303Da)

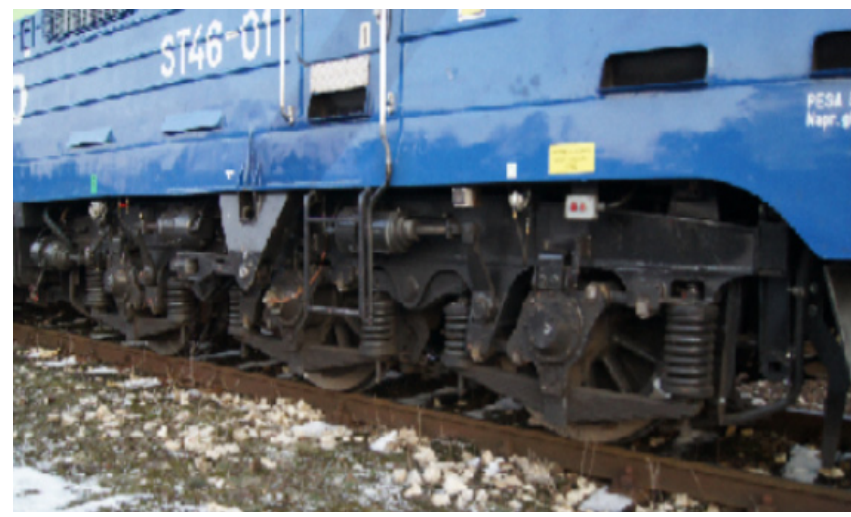

Rys.4 Widok zmodernizowanego wózka trakcyjnego

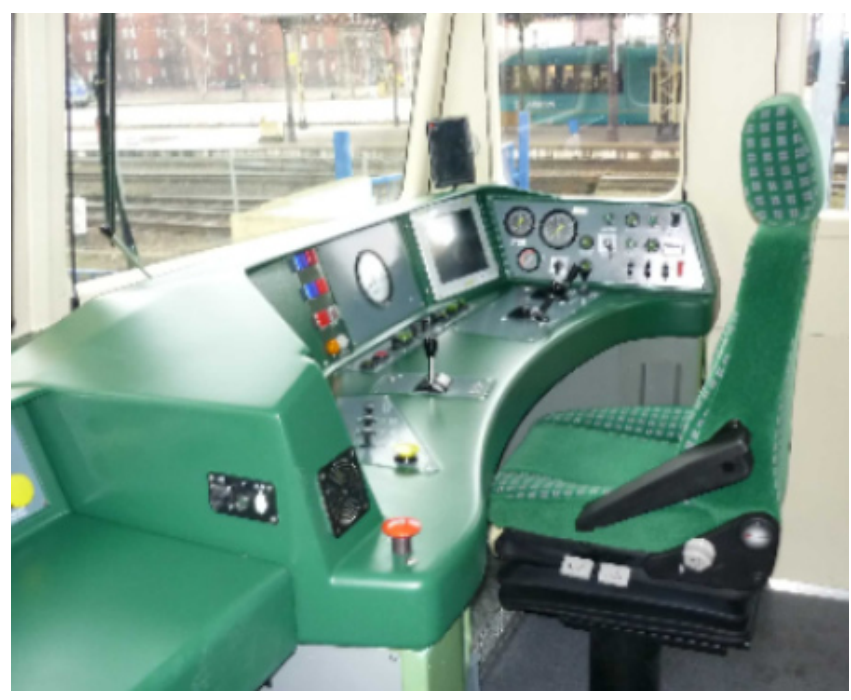

Rys.5 Wnętrze zmodernizowanej kabiny maszynisty
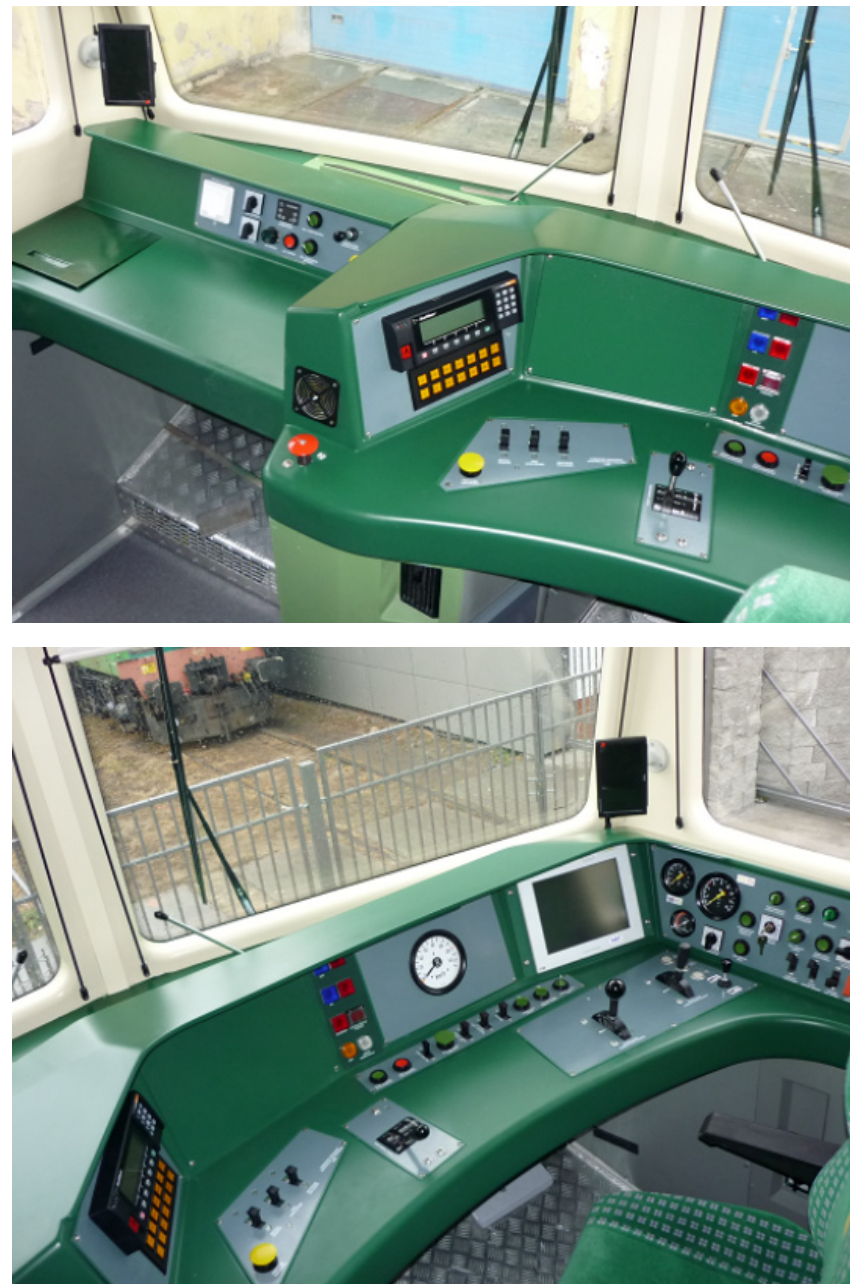

Rys.6 Widok zmodernizowanego pulpitu sterowniczego a) pulpit pomocniczy, b) pulpit główny 


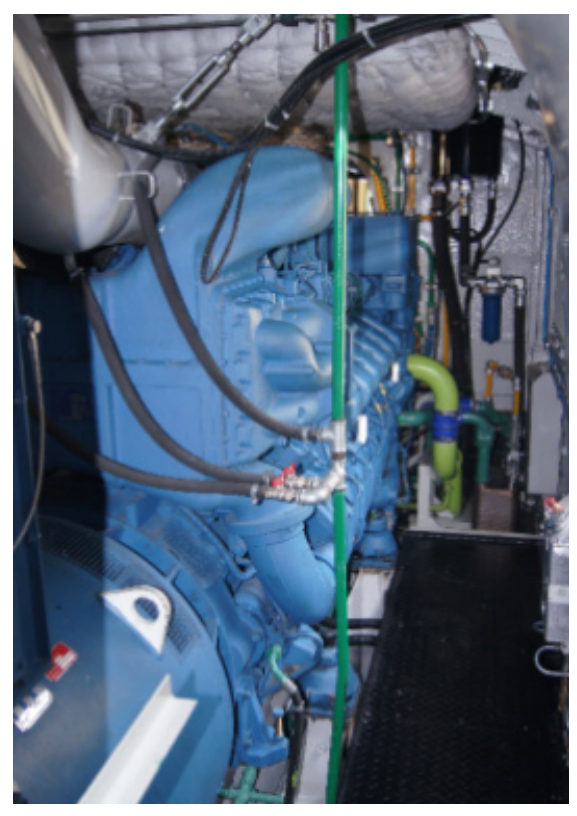

Rys. 7 Widok zespołu prądotwórczego

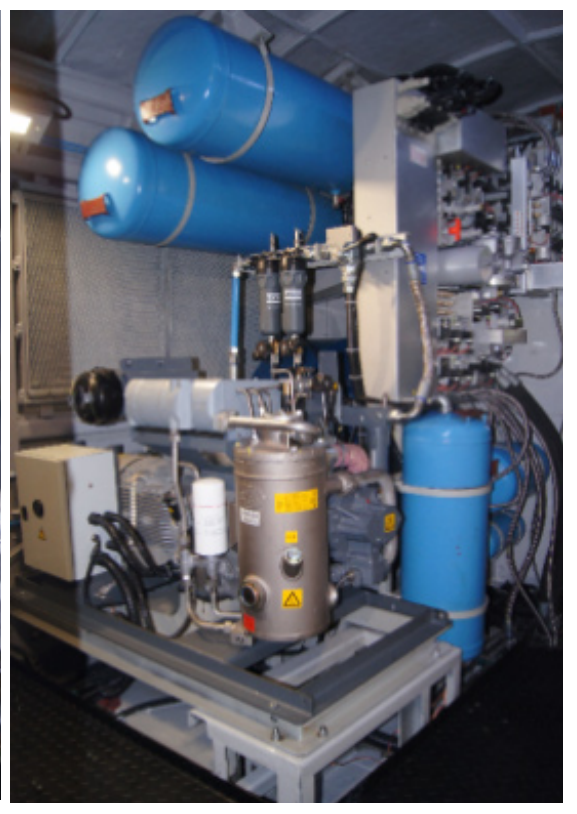

Rys. 8 Widok na sprężarkę i tablicę układu pneumatycznego

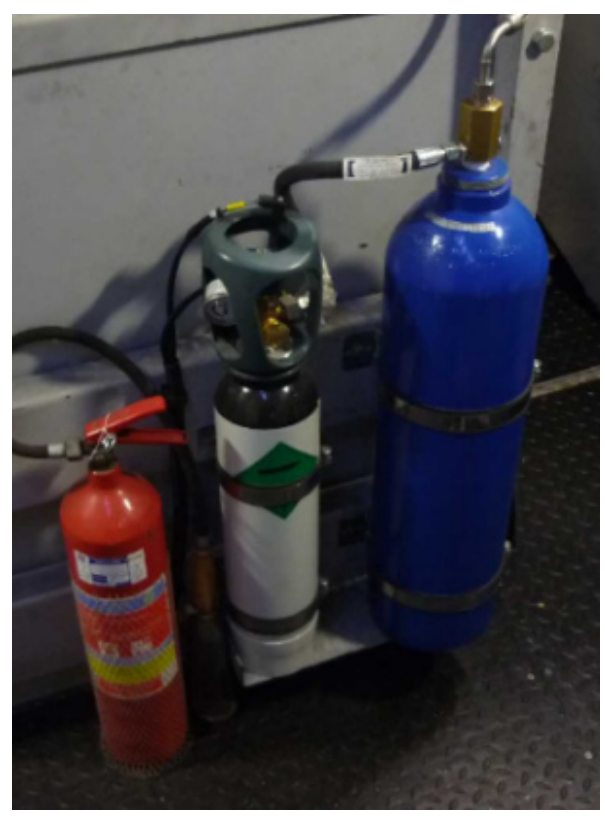

Rys. 9 Widok stałej instalacji gaszącej

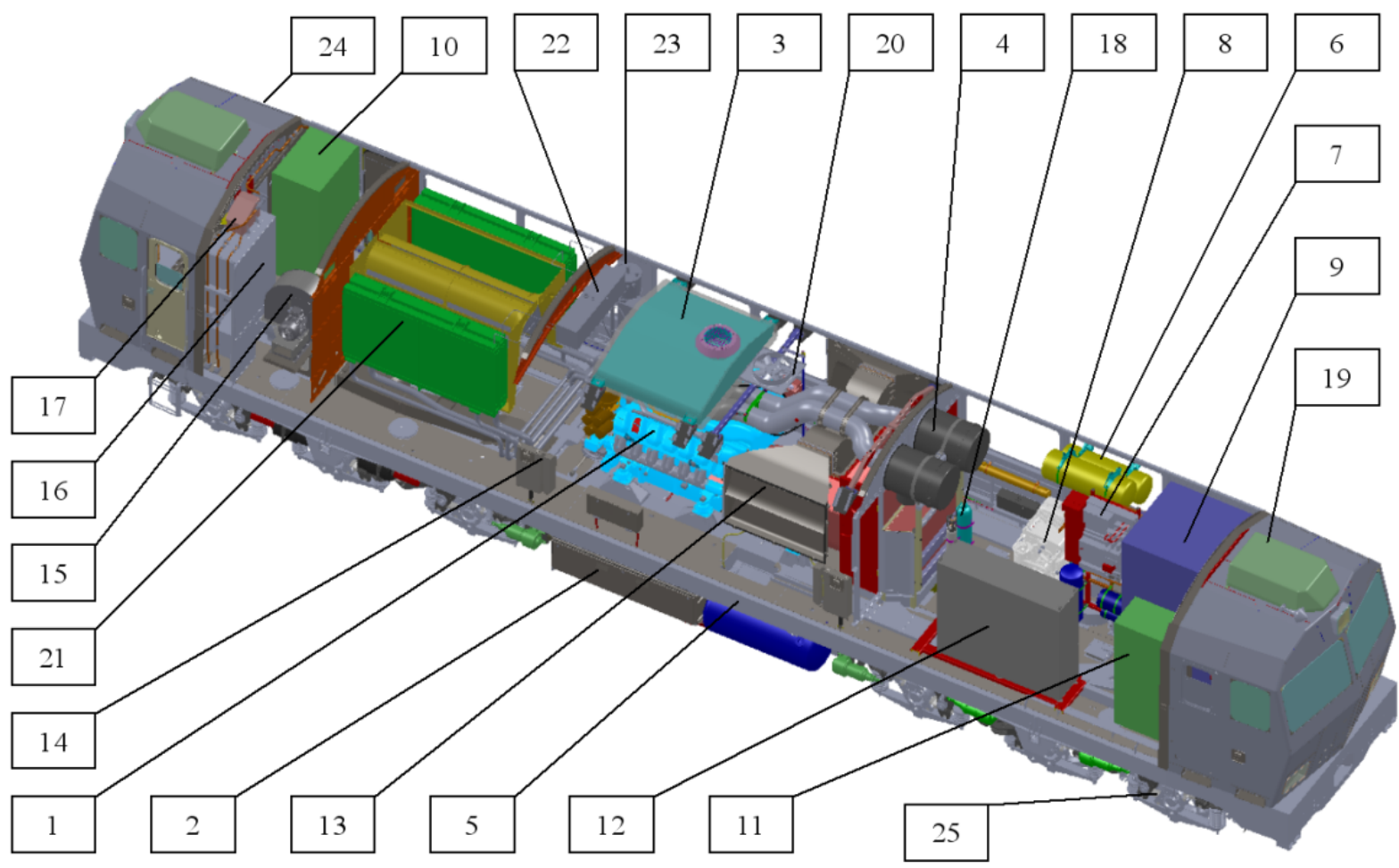

Rys. 10 Rozmieszczenie głównych maszyn i urządzeń w zmodernizowanej lokomotywie serii ST46 (303Da)

1 -zespót prqdotwórczy; 2 - baterie akumulatory; 3 -tlumik wylotu spalin; 4 -filtry powietrza; 5 -zbiorniki główne powietrza; 6-zbiorniki pomocnicze powietrza; 7 -tablica pneumatyczna; 8 -sprężarka; 9 -szafa SN; 10 - szafa NN1; 11 - szafa NN2; 12 - szafa sterujqca; 13 - kanat wentylacji zespotu pradnic; 14 - piasecznice; 15 - wentylator silników trakcyjnych; 16 - szafka odzieżowa i umywalka; 17 - uktad wodny umywalki; 18 - stała instalacja gaszaca; 19 - klimatyzator; 20 - wentylator przedziału silnikowego; 21 - zespót chłodnic; 22 - zbiornik płynu chłodzqcego; 23 - układ hydrostatyczny napędu wentylatorów chłodnic; 24 - kabina maszynisty; 25 - wózek trakcyjny

Zakres i ilość przeglądów i napraw lokomotywy ulegnie zmniejszeniu, dzięki zastosowaniu niezawodnych aparatów, urządzeń i zespołów oraz łatwej lokalizacji ich uszkodzeń. Przewidywany współczynnik gotowości technicznej do wykonywania zapla- nowanych zadań przewozowych jest szacowany powyżej $92 \%$ a przewidywany cykl przeglądowo naprawczy modernizowanej lokomotywy przedstawiono na rys.11. 


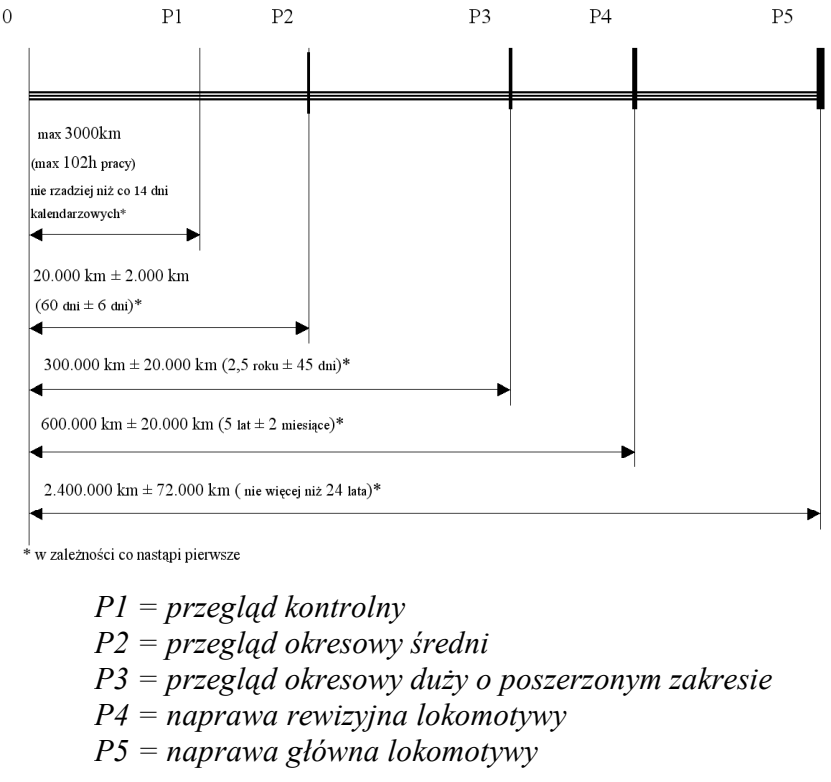

Rys.11 Cykl przeglądowo - naprawczy zmodernizowanej lokomotywy serii ST 46 (303Da)

\section{Próby i badania lokomotywy}

Zmodernizowana lokomotywa po wykonaniu w „PESA” Bydgoszcz została poddana próbom i badaniom (przez IPS „TABOR” Poznań i PESA Bydgoszcz) dla potwierdzenia parametrów technicznych i eksploatacyjnych oraz wymaganych zakresem badań koniecznych ujętych w Rozporządzeniu Ministra Infrastruktury (Dz. U. Nr 212 z dnia 12.10.2005 poz. $1772 \S 4$ pkt 1) gwarantujących uzyskanie świadectwa dopuszczenia do eksploatacji typu pojazdu kolejowego.

Ostatecznie lokomotywa została poddana następującym próbom i badaniom:

- stacjonarnym zgodnym wymaganiami Warunków Technicznych Odbioru oraz fabrycznym jazdom próbnym (luzem i z obciążeniem)

- wyznaczenia charakterystyk trakcyjnych

- analizom teoretycznym bezpieczeństwa ruchu i oddziaływania na tor oraz doświadczalnym wyznaczeniem bezpieczeństwa przed wykolejeniem

- układu hamulca, urządzeń przeciwpoślizgowych i układów związanych $\mathrm{z}$ bezpieczeństwem ruchu na torach PKP PLK S.A.

- $\quad$ wpływu lokomotywy na pracę urządzeń sterowania ruchu kolejowego i sygnalizacji oraz zakłóceń radioelektrycznych i elektromagnetycznych (wewnątrz i na zewnatrz)

- własności akustycznych (hałasu, syren akustycznych)

- oświetlenia zewnętrznego i sygnalizacji

- warunków pracy obsługi (oświetlenie, komfort termiczny i akustyczny, ergonomia, indukcyjność pola magnetycznego)

Próby i badania dały wynik pozytywny i zmodernizowana lokomotywa uzyskała świadectwo nr
T/2011/1013 dopuszczenia do eksploatacji typu pojazdu kolejowego - ważne do 30.09.2011 [6].

Obecnie lokomotywa przechodzi 6 miesięczne próby eksploatacyjne oraz przystosowywana jest do uzyskania świadectwa dopuszczenia do eksploatacji na torach kolei DB.

\section{Podsumowanie}

Zaprezentowany zakres modernizacji oraz uzyskane efekty po jej wykonaniu będą przynosiły określone efekty dla Użytkownika pod warunkiem wdrożenia do eksploatacji większej ilości zmodernizowanych lokomotyw i w dłuższym okresie czasu.

Należy również zauważyć, że proces modernizacji rozpoczął się 3 lata temu i obecnie konieczna będzie zabudowa w lokomotywie nowego silnika spełniającego wymagania poziomu IIIb w zakresie emisji składników toksycznych spalin do atmosfery.

Ponadto w wyniku wniosków z prób eksploatacyjnych mogą wystąpić dalsze wymagania Użytkownika odnośnie modernizacji innych układów i zespołów bądź wprowadzenia nowszych i bardziej niezawodnych aparatów i urządzeń.

W zakończeniu należy stwierdzić, że proces modernizacji spalinowych lokomotyw dużej mocy przeznaczonych do prac liniowych (prowadzenia pociągów pasażerskich i towarowych) na torsach PKP PLK S.A. został praktycznie zakończony i obecnie należy go wdrażać na lokomotywach niemodernizowanych.

\section{Literatura}

[1] Marciniak ;Projekty modernizacyjne spalinowych lokomotyw liniowych $i$ manewrowych wykonanych $w$ Instytucie Pojazdów Szynowych, Logistyka, 2010, nr 4.

[2] Marciniak Z.; Zmodernizowane w ostatnich latach lokomotywy elektryczne $i$ spalinowe $w$ Polsce, Technika Transportu Szynowego, 2011 nr 4.

[3] Marciniak Z., Michalak P.; Nowe oraz zmodernizowane układy i zespoty $w$ modernizowanej lokomotywie spalinowej typu 303D serii SU46, Pojazdy Szynowe 2012, nr 1.

[4] Michalak P., Bejenka K.; Specyfikacja techniczna zespołów wyposażeniowych lokomotywy ST46. Opracowanie Z1/1611/OR-9727, Bydgoszcz-Poznań, 04.2010 .

[5] Dokumentacja Techniczno - Ruchowa lokomotywy spalinowej typu 303Da serii ST46 - Opis techniczny. Opracowanie 303Da 0159-1, IPS "TABOR" Poznań, 06.2011.

[6] Opinia IPS „TABOR” w sprawie wyników badań dla zmodernizowanej lokomotywy spalinowej serii ST46 (303Da), Opracowanie 303Da 0129-1/1, IPS „TABOR” Poznań, 11.2011. 